\title{
Outcomes of Primary Concurrent Chemotherapy and Intensity Modulated Radiotherapy for Locally Advanced Laryngeal Squamous cell Carcinoma: Focus on T3 Larynx - a European Single Institution Analysis
}

\author{
Delali Adjogatse ${ }^{1}$, Francesca De Felice ${ }^{1}$, Yae-Eun Suh ${ }^{1}$, Enyi Ofo ${ }^{2}$, Jean-Pierre Jeannon ${ }^{2}$, \\ Richard Oakley ${ }^{2}$, Ricard Simo ${ }^{2}$, Mary Lei $^{1}$, and Theresa Guerrero Urbano ${ }^{1}$ \\ ${ }^{1}$ Guy's and Saint Thomas' Hospitals NHS Trust \\ ${ }^{2}$ Guy's and St. Thomas NHS Foundation Trust
}

July 2, 2020

\begin{abstract}
Introduction Treating locally advanced laryngeal squamous cell carcinoma (LSCC) with primary chemoradiotherapy (CRT) can preserve the larynx without compromising survival. However, whether this is associated with good functional outcomes remains up for debate. The aim of this study was to evaluate survival and functional outcomes in patients with locally advanced LSCC treated with primary CRT. Methods We retrospectively analysed data from all consecutive patients with stage III-IV (M0) disease treated with primary CRT between April 2010 and December 2017. Study endpoints were overall survival (OS), disease free survival (DFS), laryngectomy free survival (LFS), laryngo-oesophageal dysfunction free survival (LEDFS) and functional preservation rates. Prognostic factors were assessed by univariate and multivariate analysis. Results 69 consecutive patients treated with primary CRT were analysed. All patients were treated with Intensity Modulated Radiotherapy (IMRT). 29 patients received induction chemotherapy prior to CRT. 60 patients (87\%) received concomitant platinum-based chemotherapy, and 9 (13\%) concomitant Cetuximab. The median follow-up was 57 months (range 4-96). The completion rate for prescribed RT was $98.5 \%$. The 2 - and 5 year OS rates were $81.1 \%$ and $52.1 \%$. For patients with T3 disease, the $2-$ and 5 year OS rates were $82.4 \%$ and $61.6 \%$. Positive nodal status, N2b-N3 nodal staging, or stage IV disease were associated with poor OS on univariate, but not multivariate, analysis. Functional preservation was $69.1 \%$ at 2 years in all patients alive (68.1\% in T3 patients). The 2 -year LEDFS rate was $52 \%$. The 2- and 5-year LFS rates was $72.4 \%$ and $43.3 \%$ respectively. There was no significant difference in LFS rate between primary tumour localization, baseline laryngeal fixation or cartilage invasion. Conclusion Our study illustrates survival and functional outcomes in line with contemporary studies. The survival and function preservation rates suggest that carefully selected patients with locally advanced LSCC can successfully be treated with larynx-preserving primary CRT.
\end{abstract}

\section{Hosted file}

Anonymised main document for submission laryx.doc available at https://authorea.com/ users/338930/articles/465303-outcomes-of-primary-concurrent-chemotherapy-and-intensitymodulated-radiotherapy-for-locally-advanced-laryngeal-squamous-cell-carcinoma-focus-ont3-larynx-a-european-single-institution-analysis

\section{Hosted file}

Table 1 for submission larynx.docx available at https://authorea.com/users/338930/articles/ 465303-outcomes-of-primary-concurrent-chemotherapy-and-intensity-modulated-radiotherapy- 
for-locally-advanced-laryngeal-squamous-cell-carcinoma-focus-on-t3-larynx-a-europeansingle-institution-analysis

\section{Hosted file}

Table 2 for submission larynx.docx available at https://authorea.com/users/338930/articles/ 465303-outcomes-of-primary-concurrent-chemotherapy-and-intensity-modulated-radiotherapyfor-locally-advanced-laryngeal-squamous-cell-carcinoma-focus-on-t3-larynx-a-europeansingle-institution-analysis

\section{Hosted file}

Table 3 for submission larynx.docx available at https://authorea.com/users/338930/articles/ 465303-outcomes-of-primary-concurrent-chemotherapy-and-intensity-modulated-radiotherapyfor-locally-advanced-laryngeal-squamous-cell-carcinoma-focus-on-t3-larynx-a-europeansingle-institution-analysis 
Figure 1. Kaplan-Meier Survival curves of overall- and laryngectomy-free survival

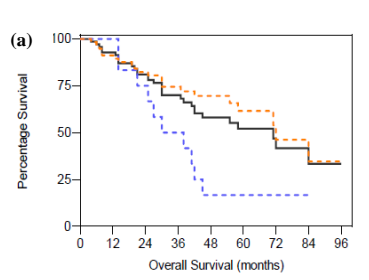

(c)

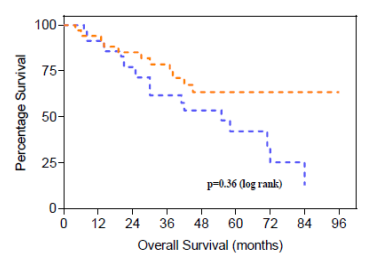

(b)
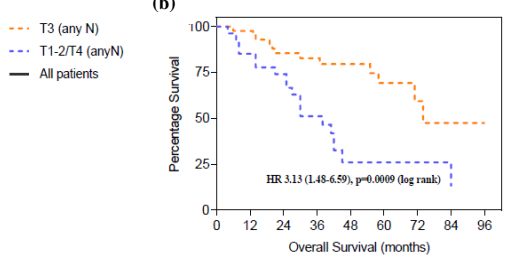

(d)

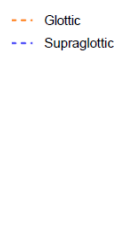

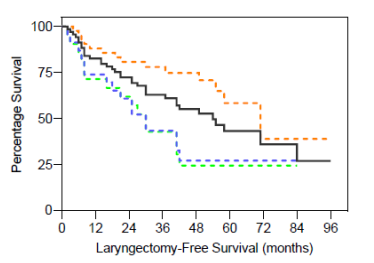

-.. Node positive

Node negative
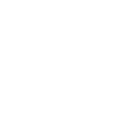

- All patien

-.. Node negative

$\mathrm{N} 2 \mathrm{~b}+$

(a) Overall Survival - all patients $(\mathrm{n}=69)$, T3anyN $(\mathrm{n}=57)$, T1-2anyN/T4anyN $(\mathrm{n}=12)$; (b) Overall Survival by nodal status - node positive $(\mathrm{n}=28)$, node negative (41); (c) Overall Survival glottic $(\mathrm{n}=33)$ versus supraglottic $(\mathrm{n}=35)$; (d) Laryngectomy-free Survival - All patients $(\mathrm{n}=69)$, Stage IV $(\mathrm{n}=23)$, Node negative $(\mathrm{n}=41)$, N2bN3 $(\mathrm{n}=20)$.

\section{Hosted file}

Table 4 for submission larynx.docx available at https://authorea.com/users/338930/articles/ 465303-outcomes-of-primary-concurrent-chemotherapy-and-intensity-modulated-radiotherapyfor-locally-advanced-laryngeal-squamous-cell-carcinoma-focus-on-t3-larynx-a-europeansingle-institution-analysis 